\title{
Hepatoprotective and antineoplastic potencial of red propolis produced by the bees Apis mellifera in the semiarid of Rio Grande do Norte, Brazil ${ }^{1}$
}

\author{
Jardel B. Silva ${ }^{2 *}$, Kaliane A.R. Paiva ${ }^{2}$ (D), Kizzy M.F.M. Costa ${ }^{2}$ (D), Geysa A. Viana², \\ Hélio N. Araújo Júnior ${ }^{2}$ (D), Lorena S. Bezerra ${ }^{3}$, Carlos I.A. Freitas ${ }^{2}$ \\ and Jael S. Batista ${ }^{2}$
}

\begin{abstract}
Silva J.B., Paiva K.A.R., Costa K.M.F.M., Viana G.A., Araújo Júnior H.N., Bezerra L.S., Freitas C.I.A. \& Batista J.S. 2019. Hepatoprotective and antineoplastic potencial of red propolis produced by the bees Apis mellifera in the semiarid of Rio Grande do Norte, Brazil. Pesquisa Veterinária Brasileira 39(9):744-756. Centro de Ciências Agrárias, Universidade Federal Rural do Semi-Árido, Av. Francisco Mota 572, Costa e Silva, Mossoró, RN 59625-900, Brazil. E-mail: jardelbezerra@bol.com.br

The objective of this study was to evaluate the hepatoprotective effect of the honey bee Apis mellifera ethanolic extract of the red propolis, obtained in four municipalities of the Rio Grande do Norte semi-arid region, through an in vitro evaluation of the antineoplastic potential in human hepatic carcinoma (HepG2) and normal cell lines (L929), and from the comet assay in hepatic cell lines (ZF-L hepatocytes) to evaluate the genoprotective potential of the extract. The hepatoprotective effect was also evaluated in vivo by the induction of chronic experimental hepatic lesions in rodents (Rattus norvegicus Berkenhout, 1769), Wistar line, by intraperitoneal administration of thioacetamide (TAA) at the dose of $0.2 \mathrm{~g} / \mathrm{kg}$. The animals were distributed in the following experimental groups: G1 (control), G2 (treated with $500 \mathrm{mg} / \mathrm{kg}$ ethanolic extract of propolis), G3 (treated with $500 \mathrm{mg} / \mathrm{kg}$ of ethanolic extract and TAA) and G4 (treated with TAA). All rats were submitted to serum biochemical, macroscopic, histological and stereological biochemical exams of the liver. It was verified the genoprotective effect of red propolis since the mean damages promoted to DNA in cells tested with the extract were significantly lower than the mean of the positive control damage (hydrogen peroxide). The red propolis extract did not present cytotoxic activity to the tumor cells of human liver cancer, as well as to normal ones. The absence of cytotoxicity in normal cells may indicate safety in the use of the propolis extract. The results of the serum biochemical evaluation showed that the serum levels of the aminotransferase enzymes (AST) did not differ significantly between G1, G2 and G3 when compared to each other. G4 showed significant increase in levels compared to the other groups, indicating that the administration of the extract did not cause liver toxicity, as well as exerted hepatoprotective effect against the hepatic damage induced by TAA. The G3 and G4 animals developed cirrhosis, but in G3 the livers were characterized by the presence of small regenerative nodules and level with the surface of the organ, whereas in G4 the livers showed large regenerative nodules. The livers of the G1 and G2 animals presented normal histological appearance, whereas the livers of the G3 animals showed regenerative nodules surrounded by thin septa of connective tissue, and in G4 the regenerative nodules were surrounded by thick septa fibrous connective tissue. The analysis of the hepatic tissues by means of stereology showed that there was no statistical difference between the percentage of hepatocytes, sinusoids, and collagens in G1 and G2.
\end{abstract}

\footnotetext{
${ }^{1}$ Received on April 5, 2019.

Accepted for publication on April 19, 2019.

${ }^{2}$ Centro de Ciências Agrárias, Universidade Federal Rural do Semi-Árido (UFERSA), Av. Francisco Mota 572, Costa e Silva, Mossoró, RN 59625-900, Brazil. *Corresponding author: jardelbezerra@bol.com.br
}

\footnotetext{
${ }^{3}$ Centro de Ciências da Saúde, Universidade de Fortaleza (Unifor), Av. Washington Soares 1321, Edson Queiroz, Fortaleza, CE 60811-905, Brazil.
} 
In G3 the percentage of hepatocytes, sinusoids, and collagen did not differ significantly from the other groups. It was concluded that the ethanolic extract of the red propolis exerted a hepatoprotective effect, because it promoted in vitro reduction of the damage to the DNA of liver cells, antineoplastic activity in human hepatocellular carcinoma cell line (HepG2) and did not exert cytotoxic effect in normal cells or was able to reduce liver enzyme activity and the severity of cirrhosis induced by TAA in vivo.

INDEX TERMS: Hepatoprotection, antineoplastic potencial, red propolis, bees, Apis mellifera, Rio Grande do Norte, Brazil, northeast, cytotoxicity, genoprotection, rodents, rats.

RESUMO.- [Potencial hepatoprotetor e antineoplásico da
própolis vermelha produzida pela abelha Apis mellifera
no semiárido do Rio Grande do Norte, Brasil.] Este estudo objetivou avaliar o efeito hepatoprotetor do extrato etanólico da própolis vermelha da abelha Apis mellifera, obtido em quatro municípios do semiárido do Rio Grande do Norte, mediante avaliação in vitro do potencial antineoplásico em linhagens de células de carcinoma hepático humano (HepG2) e em linhagens de células normais (L929), além do ensaio cometa em linhagens de células hepáticas (hepatócitos ZF-L) para avaliar o potencial genoprotetor do extrato. 0 efeito hepatoprotetor também foi avaliado in vivo através da indução de lesões hepática experimental crônica em roedores da espécie Rattus norvegicus (Berkenhout, 1769), linhagem Wistar, pela administração intraperitoneal de tioacetamida (TAA) na dose de $0,2 \mathrm{~g} / \mathrm{kg}$. Os animais foram distribuídos nos seguintes grupos experimentais: G1 (controle), G2 (tratados com $500 \mathrm{mg} / \mathrm{kg}$ de extrato etanólico da própolis), G3 (tratados com $500 \mathrm{mg} / \mathrm{kg}$ de extrato etanólico e TAA) e G4 (tratados com TAA). Todos os ratos foram submetidos aos exames bioquímico sérico, anatomopatológico macroscópico, histológico e esteriológico do fígado. Foi constatado o efeito genoprotetor da própolis vermelha uma vez que as médias dos danos promovidos ao DNA em células testadas com o extrato foram significativamente inferiores à média dos danos do controle positivo (peróxido de hidrogênio). 0 extrato da própolis vermelha não apresentou atividade citotóxica para células tumorais de câncer de fígado humano, bem como para normais. A ausência de citotoxicidade em células normais, tal como constatado, pode indicar segurança no uso do extrato da própolis. Os resultados da avaliação bioquímica sérica demonstraram que os níveis séricos das enzimas aminotransferase (AST) não diferiram significativamente entre G1, G2 e G3, quando comparadas entre si. No G4 houve aumento significativo dos níveis em relação aos demais grupos, indicando que a administração do extrato não causou toxicidade hepática, bem como exerceu efeito hepatoprotetor frente ao dano hepático induzido pela TAA. Os animais dos G3 e G4 desenvolveram cirrose, porém no G3 os fígados caracterizaram-se pela presença de pequenos nódulos regenerativos e nivelados com a superfície do órgão, enquanto que no G4 os fígados apresentaram grandes nódulos regenerativos. Os fígados dos animais G1 e G2 apresentaram aspecto histológico normal, enquanto que os fígados dos animais do G3 apresentaram nódulos regenerativos circundados por finos septos de tecido conjuntivo, e nos do G4 os nódulos regenerativos foram circundados por espessos septos de tecido conjuntivo fibroso. A análise dos tecidos hepáticos por meio de estereologia mostrou que não houve diferença estatística entre o percentual de hepatócitos, sinusoides e colágenos nos G1 e G2. No G3 o percentual de hepatócitos, sinusoides e colágeno não diferiu significativamente dos demais grupos.
Concluiu-se que o extrato etanólico da própolis vermelha exerceu efeito genoprotetor, por promover in vitro redução do dano ao DNA de células hepáticas, atividade antineoplásica em linhagem celular de carcinoma hepatocelular humano (HepG2) e não exerceu efeito citotóxico em células normais ou efeito hepatoprotetor in vivo com diminuição da gravidade da cirrose induzida por TAA.

TERMOS DE INDEXAÇÃO: Hepatoproteção, antineoplásicos, própolis vermelha, abelhas, Apis mellifera, Rio Grande do Norte, Brasil, nordeste, citotoxicidade, genoproteção, ratos.

\section{INTRODUCTION}

Propolis is composed of resinous and balsamic material collected by bees on tree branches, flowers, pollen, buds, and exudates. It is a complex mixture in which bees add salivary secretions in the hive. The resin is used by bees to protect the hive against the proliferation of microorganisms, and to maintain internal temperature, repairing honeycombs, embalming insects, and closing holes and cracks (Silva et al. 2006, Zilse \& Silva 2012).

Depending on its color, odor, and consistency, the characteristics of propolis are associated with its region of origin, botanical source, and chemical composition. Thus, propolis can range from green, red to brown, black, and yellow (Bankova 2005, Lopes 2014). Red propolis is in the newest, being the 13th type of cataloged propolis, which revealed a chemical composition rich in isoflavonoids. Its botanical origin is from the Dalbergia ecastophyllum plant, a legume rich in flavonoids. This species is reported to be from Cuba and Venezuela, originating from the plants Clusia nemorosa and Clusia scrobiculata, Clusiaceae family (Li et al. 2008, Bueno-Silva et al. 2013).

Brazil is the world's second-largest producer of propolis, exporting about 160 tons annually, being only after China. Besides being good for health, the consumption of organic products encourages rural producers to maintain good agricultural practices for environmental preservation, using soil, water, air and other natural resources responsibly (Lima 2006, Oldoni et al. 2015).

The literature often shows the biological properties of propolis related to the presence of a variety of biologically active compounds, especially the phenolic compounds, which include flavonoids with outstanding antioxidant and anti-inflammatory activities and components (Al Naggar et al. 2016). Different research has shown that the significant amounts of antioxidants in the diet contribute to the prevention of serious, chronic and inflammatory diseases, which are associated with the formation of radicals during the oxidation process, since natural antioxidants can decrease oxidative 
stress and consequently promote oxidative stress protection against DNA damage (Carratú \& Sanzini 2005, Horst \& Lajolo 2012, Teerasripreecha et al. 2012, Daleprane \& Abdalla 2013).

As the liver is the main organ of metabolism of compounds, many liver diseases appear by its exposure to toxic substances, and the oxidative stress promoted by these substances is very important in the pathophysiological mechanisms of these diseases (Voican et al. 2011). As the propolis has bioactive substances with potential antioxidant, anti-inflammatory, and genoprotective, the red propolis ethanolic extract may prevent or minimize damage to liver cells when exposed to hepatotoxic substances. Thus, the objective of this study was to evaluate the hepatoprotective potential of the Apis mellifera red propolis ethanolic extract obtained in the semiarid region of Rio Grande do Norte, Brazil, through the chronic experimental induction of liver damage in rodents (Rattus norvegicus Berkenhout, 1769), Wistar strain, using thioacetamide, the in vitro evaluation of the antineoplastic effect of human liver carcinoma (HepG2) cell line extract, and the genoprotective potential in liver cell lines (hepatocytes ZF-L).

\section{MATERIALS AND METHODS}

\section{Red propolis extract}

Acquisition and elaboration of propolis extract. Four samples of red propolis produced by the bee Apis mellifera from hives installed in the municipalities of Parnamirim (samples A and B) and Mossoró (samples C and D) were collected from February to March 2018. The preparation of the extracts used samples of $200 \mathrm{~g}$ of propolis, subdivided into small portions, and submitted to drying in an air circulation oven at $40^{\circ} \mathrm{C}$ for $48 \mathrm{~h}$, and then crushed in a domestic blender. Cold maceration was performed at a ratio of 1:6.25 (m/v) for each $1 \mathrm{~g}$ of crushed propolis, using $6.25 \mathrm{~mL}$ of $70^{\circ} \mathrm{GL}$ cereal alcohol. The samples were placed in properly identified amber glass and shaken manually for 30 seconds daily for 20 consecutive days of infusion, according to Garcia et al. (2004a). In the next step, the filtering of the supernatant was performed on filter paper and later on cotton, to retain all the insoluble particles. The filtration was refrigerated in a freezer $\left(-20^{\circ} \mathrm{C}\right)$ for 45 minutes to remove the wax and then another supernatant filtration was done, followed by centrifugation, obtaining the ethanolic extracts of the propolis.

Estimation of total phenol content. The Folin Ciocalteu method (Singleton et al. 1999) was used to determine phenolic content. Each propolis extract sample $(5 \mathrm{~mL})$ was diluted into $50 \mathrm{~mL}$ with distilled water. This solution $(0.5 \mathrm{~mL})$ was mixed with $2.5 \mathrm{~mL}$ of $0.2 \mathrm{~N}$ Folin Ciocalteu reagent for 5 minutes and $2 \mathrm{~mL}$ of $75 \mathrm{~g} / \mathrm{L}$ sodium carbonate $\left(\mathrm{Na}_{2} \mathrm{CO}_{3}\right)$.

After 2 hours of incubation at room temperature, the absorbance of the reaction mixture was measured at $760 \mathrm{~nm}$ against a methanol blank in a spectrophotometer (Series 2000, CECIL Instruments, Cambridge, England). Gallic acid (Sigma-Aldrich Chemie, Steinheim, Germany) (0-200mg/L) was the standard used to obtain the calibration curve. The mean of three readings was used, and the total phenolic content was expressed in mg of gallic acid equivalents (GAE) $/ 100 \mathrm{~g}$ of propolis.

Estimation of total flavonoid content. Total flavonoid content was determined using the Dowd Method adapted by Grand et al. (1994). Thus, there were $5 \mathrm{~mL}$ of $2 \%$ aluminum chloride (AlCl3) (Labosi, Paris, France) mixed in methanol (Fluka Chemie, Switerland) with the same volume as a propolis extract solution $(0.01 \mathrm{mg} / \mathrm{mL})$. Then, a blank solution of a $5 \mathrm{~mL}$ propolis extract solution was added to $5 \mathrm{~mL}$ methanol without $\mathrm{AlCl} 3$, and then absorbance readings at
$415 \mathrm{~nm}$ were taken on a spectrophotometer (Series 2000, CECIL CE 2041, Cambridge, England). Total flavonoid content was determined using a standard quercetin curve (Sigma-Aldrich Chemie, Steinheim, Germany) (0-50mg/L). The mean of three readings was used and expressed as mg quercetin equivalents $(\mathrm{QE}) / 100 \mathrm{~g}$ of propolis.

Antioxidant activity by the DPPH method. For the assessment of the antioxidant activity, the in vitro photocolorimetric method of free radical DPPH (2.2-diphenyl-1-picrylhydrazine) was used, described by Mensor et al. (2001). The extracts were diluted in methanol at different concentrations $(100,50,40,20,5$, and 2ppm). Then, $1 \mathrm{~mL}$ of each concentration was placed in test tubes along with $1 \mathrm{~mL}$ of a $60 \mu \mathrm{mol} / \mathrm{L}$ DPPH methanolic solution. After 30 minutes, the absorbance of the samples was measured by spectrophotometer at a wavelength of $520 \mathrm{~nm}$, with only methanol as blank.

The inhibition percentage for each extract concentration was obtained from the absorbance ratio with the absorbance of a solution containing $1 \mathrm{~mL}$ methanol and $1 \mathrm{~mL}$ DPPH solution. All analyses were triplicated. After the free radical percentage inhibition values, they were analyzed in Origin 7.0 Software to obtain a graph showing values, calculating the $50 \%$ inhibitory concentration of the DPPH radical (IC50).

Genoprotective potential assessment. Sample A of the red propolis extract was used to assess the genoprotective effect since it presented better results in terms of total phenols, total flavonoids, and antioxidant activity. The comet assay assessed the genoprotective effect in liver cell line (hepatocytes ZF-L) $\left(0.7 \times 10^{5}\right.$ cells $\left./ \mathrm{mL}\right)$ cultured in DMUL (Dulbecco modification of Minimum Essential Media; GIBCO ${ }^{\circledR}$ ) supplied with $10 \%$ fetal cattle serum and $1 \%$ antibiotics. Liver cells were exposed to hydrogen peroxide $\left(\mathrm{H}_{2} \mathrm{O}_{2} ; 150 \mu \mathrm{M}\right.$ for 2 hours exposure) for genotoxicity induction (positive control) and sterile distilled water (negative control). Cell cultures were also co-treated with increasing concentrations of propolis $(100,250$ and $500 \mu \mathrm{g} / \mathrm{mL})$ and $\mathrm{H}_{2} \mathrm{O}_{2}(150 \mu \mathrm{M})$ for 2 hours at $37^{\circ} \mathrm{C}$ in a $5 \% \mathrm{CO}_{2}$ atmosphere (test group).

The cells were homogenized in $0.8 \%$ agarose and spread on prepared slides and immersed in lysis solution for 1 hour, followed by neutralization. Subsequently, the slides were kept in electrophoresis buffer at $4^{\circ} \mathrm{C}$ for 20 minutes, followed by running for 20 minutes, $1.6 \mathrm{Vcm}^{-1}$. The slides were stained in an ethidium bromide solution $(20 \mu \mathrm{g} / \mathrm{mL})$ and analyzed using a fluorescence microscope. The degree of DNA damage was visually identified by analyzing the tail formed by the DNA fragments, and the tail size was proportional to the extent of the damage caused (Mezzalira et al. 2014). One hundred comets per slide were analyzed and classified by visual analysis into five categories $(0,1,2,3$ and 4$)$, representing the percentage of DNA in the comet's tail, showing the degree of damage in the cell (Lovell et al. 1999).

The damage index (DI) was obtained by the following formula:

$$
D I=\sum_{i=0}^{4} n_{i} \times i
$$

In which $n_{i}$ is the number of cells with damage level $i(0,1,2,3$, or 4$)$.

The protective effect of test samples on $\mathrm{H}_{2} \mathrm{O}_{2}$-induced genotoxicity (150 $\mu \mathrm{M}$ for 2 hours exposure) was calculated according to Waters et al. (1990), and the formula: \% reduction $=(A-B / A-C) \times 100$, in which A corresponds to the DI induced by $\mathrm{H}_{2} \mathrm{O}_{2}$, B corresponds to the DI induced by genoprotective treatment $\left(\mathrm{H}_{2} \mathrm{O}_{2}+\right.$ test sample), and $\mathrm{C}$ corresponds to the DI for the negative control (distilled water).

Statistical analysis. The ANOVA and Newman-Keuls tests were used in the Prism ${ }^{\circledR}$ version 5.0 software (GraphPad Prism Software) 
for the statistical analysis of the genoprotective effect, and the results were considered significant when $\mathrm{p}<0.05$.

Antineoplastic effect. The red propolis extract sample A was used to assess the antineoplastic activity through the cytotoxicity assay in a human hepatocellular carcinoma cell line (HepG2). For the comparison and evaluation of the selective effect of cytotoxicity, a healthy cell line (fibroblasts-L929) was used.

The evaluation of the cytotoxic activity of the red propolis ethanolic extract in neoplastic (HepG2) and normal cells (fibroblasts-L929) was performed by the MTT (3-bromide (4.5-dimethyl2 thiazolyl)2.5-diphenyl-2H tetrazolium) according to the methodology described by Mosmann (1983). The cells were added in a 96-well plate $\left(1.5 \times 10^{5}\right.$ cells/well), supplied with $10 \%$ fetal bovine serum and treated with red propolis extract at concentrations of

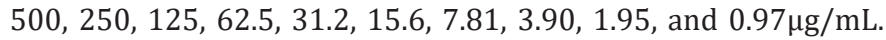
Subsequently, they were incubated for $24 \mathrm{~h}$ in a $5 \% \mathrm{CO}_{2}$ greenhouse at $37^{\circ} \mathrm{C}$, and then $25 \mu \mathrm{L}$ of the MTT solution was added, and the absorbance was read on a $595 \mathrm{~nm}$ spectrophotometer.

Data analysis. The mean absorbance data from the samples were compared by analysis of variance ANOVA followed by Tukey post-test using the Prisma version 5.0 program (GraphPad Software), with a significance level of $\mathrm{p}<0.05$. The percentage of inhibition xlog of concentration and its $\mathrm{IC}_{50}$ and respective confidence intervals (95\%) from nonlinear regression were also recorded using the Prisma version 5.0 program (GraphPad Software).

\section{In vivo hepatoprotective activity}

Experimental animals and bioethics. Forty male adult rodents (Rattus norvegicus Berkenhout, 1769), Wistar strain, 60-day-old, weight of $200 \mathrm{~g}$ were used, provided by the Rio Grande do Norte State University (UERN) vivarium. The animals were housed in propylpropylene cages, kept at temperature $\left(21^{\circ} \mathrm{C} \pm 2^{\circ} \mathrm{C}\right)$ and controlled humidity (55\% $\pm 10 \%)$ with 12 hours light/dark photoperiod, fed with commercial food (Purina ${ }^{\circledR}$ ) and ad libitum water throughout the experimental procedure. According to the manufacturer (Purina ${ }^{\circledR}$ ), the food composition was approximately $23 \%$ of crude protein, $4 \%$ of total lipid, $5 \%$ of fiber and $12 \%$ of minerals.

The experimental protocols used in this study were submitted to the approval of the "Ethics Committee on Animal Use" of the "Rio Grande do Norte State University" (CEUA-UERN), with protocol number 002/2018.

Experimental design of liver cirrhosis. The animals were divided into four experimental groups and the serum biochemical parameters indicating liver damage, macroscopic and histopathological liver parameters were evaluated.

Group I (Control): It had ten animals that received via oral only water daily for 14 weeks.

Group II: It had ten animals that received via oral $500 \mathrm{mg} / \mathrm{kg}$ propolis red ethanolic extract daily for 14 weeks.

Group III: It had ten animals that received via oral $500 \mathrm{mg} / \mathrm{kg}$ propolis red ethanolic extract daily for 14 weeks and $0.2 \mathrm{~g} / \mathrm{kg}$ intraperitoneal thioacetamide (TAA) three times a week during the same period.

Group IV: It had ten animals that received intraperitoneal $0.2 \mathrm{~g} / \mathrm{kg}$ TAA three times a week for 14 weeks.

The sample of red propolis extract A was used to evaluate the in vivo hepatoprotective effect. The route of administration and the dose of TAA used to induce liver cirrhosis were established as described by Amin et al. (2012). The choice of administration routes and propolis extract doses were also based on previous studies in the literature and established as described by Mahmoud et al. (2015).
Blood samples collection and processing. The animals were anesthetized using ketamine hydrochloride solution $(100 \mathrm{mg} / \mathrm{kg}$ ) and xylazine hydrochloride $(100 \mathrm{mg} / \mathrm{kg}$ ) by intraperitoneal route. Then, a laparotomy was performed through an incision over the alba line to allow access to the hepatic vein. From each animal, $3 \mathrm{~mL}$ of blood was collected using a 30x0.7 syringe and needle, placed in tubes without the addition of anticoagulant and then tilted and kept at rest to obtain blood serum. The serum obtained was stored in a freezer $\left(-80^{\circ} \mathrm{C}\right)$ for further biochemical analysis.

Biochemical analysis of liver function. Blood serum samples were analyzed to determine the following liver damage markers: aspartate aminotransferase (AST), alanine aminotransferase (ALT), albumin (ALB), total protein (TP), glucose (GLUC), triglycerides (TRIG) and total bilirubin (BILT). The samples were tested by commercial reagents (LABTEST, Belo Horizonte/MG) and then read in a biochemical analyzer by spectrophotometry (BIOPLUS 2000).

Pathological examination. Immediately after the blood collection, the animals were euthanized by cervical dislocation under deep anesthesia. Then, the animals were individually weighed with precision scales and submitted to necropsy, using the technique proposed by Vasconcelos (1996), with an external examination of the animal, followed by the opening of the thoracic, abdominal and cranial cavities and the macroscopic examination of the organs. Each animal's liver was weighed and examined to identify possible changes from the normal pattern, especially considering changes in weight, size, color, and consistency, as well as the presence of nodules.

Analysis of the results. The mean \pm standard deviation was used to express the data obtained from serum biochemical parameters and liver weight. To evaluate possible differences between treatments, the data obtained were submitted to one-way ANOVA analysis of variance, followed by Tukey's multiple comparison post-test, considering $\mathrm{p}<0.05$ as significant. Data were analyzed using the SAS statistical program (2002).

Histopathological examination. Organ fragments were fixed in $10 \%$ formaldehyde buffered solution and routinely processed for histology, embedded in paraffin, cut to $5 \mu \mathrm{m}$ in thickness and stained with hematoxylin-eosin (HE). Liver tissue specimens were also subjected to Gomori trichrome staining to identify collagen fibers, as established by Andrade et al. (1999).

Stereological assessment. The livers were sectioned following a uniform and systematic random sampling pattern, as described by Marcos et al. (2012). In two liver fragments stained by the hematoxylin-eosin and Gomori trichrome method, five microscopic fields were randomly evaluated per animal and captured on the 20x objective using a video microscope system (Leica). A total of 20 blindly microscopic fields for each animal were analyzed. A test system composed of 50 test points (PT) was superimposed over the image of each field using the Pro-Plus Image software (Version 4.5.0.29.), evaluating hepatocytes, sinusoids and collagen fibers. The volumetric density (Vv) of these parameters was evaluated by the following formula: $\mathrm{Vv}=\mathrm{PP} / \mathrm{PT}(\%)$ (PP represents the points reaching the structure).

The values were expressed as mean \pm standard deviation, and the minimum and maximum values were expressed using the SAS version 8.0 statistical program. After analyzing the parametric assumptions, statistical differences between the different experimental groups were obtained by analysis of variance (One-Way ANOVA), followed by Tukey's test. Percentage of data underwent sine arc transformation $\sqrt{\mathrm{x}}$. 


\section{RESULTS AND DISCUSSION}

\section{Phenols and total flavonoids contents}

The phenol and total flavonoid contents ranged from $74.92 \pm 0.51$ to $141.07 \pm 1.27 \mathrm{mg} \mathrm{GAE} / 100 \mathrm{~g}$ and $2.42 \pm 0.17$ to $8.35 \pm 0.28 \mathrm{mg} \mathrm{QE} / 100 \mathrm{~g}$, respectively (Table 1 ). The extracts made with red propolis from Parnamirim had higher levels of phenols and total flavonoids, observing that the levels vary according to the location of the propolis. Thus, this data is similar to those data published in the literature, which stated that the phenol and total flavonoid contents in a propolis sample are closely related to the flora ecology of each region visited by the bees (Cardinault et al. 2012, Nunes \& Guerreiro 2012). Other studies also showed that the red propolis collected in Alagoas (Frozza et al. 2013), Cuba (Piccinelli et al. 2005) and China (Hatano et al. 2012) had a varied chemical composition and contained significant amounts of phenols and total flavonoids. Several studies highlight that many biological functions of the propolis can be attributed to its antioxidant and anti-inflammatory components, promoted by phenolic compounds (Freitas et al. 2008, Lustosa et al. 2008, Araújo et al. 2016). Thus, the finding of high levels of phenols and total flavonoids are indicators of the quality of red propolis from Rio Grande do Norte.

\section{Antioxidant activity}

The ethanolic extract of red propolis was submitted to the antioxidant activity test, using the DPPH radical sequestration methodology. As the antioxidant activity is the ability to eliminate reactive oxygen/free radical species by hydrogen donation, the DPPH reduction test is used as a stable free radical to verify the antioxidant activity of different propolis extracts of different bees (Ahn et al. 2007). The sequestering capacity of the DPPH radical is represented by the $\mathrm{IC}_{50}$ values $(\%)$ of the samples compared to pure quercetin, used as a reference standard. Thus, the lower the $\mathrm{IC}_{50}$ value (\%), the greater the sequestering capacity of the radical and the higher the antioxidant activity.

The antioxidant activity ranged from $141.07 \pm 0.21 \mu \mathrm{g} / \mathrm{mL}$ to $54.14 \pm 1.50 \mu \mathrm{g} / \mathrm{mL}$ for propolis samples collected from Mossoró and Parnamirim, respectively (Table 1). Melo et al. (2010) classified the antioxidant activity of an extract as good ( IC $_{50}<65 \mu \mathrm{g} / \mathrm{mL}$ ), moderate (IC50 $<152 \mu \mathrm{g} / \mathrm{mL}$ ) and low activity (IC50 $>152 \mu \mathrm{g} / \mathrm{mL}$ ). This classification showed that in general, the red propolis of this study had an antioxidant activity that ranged from good (samples A and B) to moderate (samples C and D). In a study by Frozza et al. (2013), the red propolis collected in Sergipe had an $\mathrm{IC}_{50}$ of $270 \mu \mathrm{g} / \mathrm{mL}$. Similar results were obtained by Pinheiro (2009) with red propolis from the same geographical region, with an $\mathrm{IC}_{50}$ of $294 \mu \mathrm{g} / \mathrm{mL}$. Thus, the red propolis samples of this study had expressive $\mathrm{IC}_{50}(\%)$, when compared with these authors.

After finding a high antioxidant activity of red propolis from Alagoas, Aguiar et al. (2018) suggested that it can be used to help in the treatment of degenerative diseases, including Alzheimer's. From the point of view of chemical composition and antioxidant activity, the results in this study are very promising, and the red propolis of Rio Grande do Norte can be a viable alternative economically and with pharmacological efficacy.

\section{Genoprotective effect}

Considering that DNA damage can interfere with essential cellular processes such as replication and transcription and can lead to cell death and induce cancer-causing mutations that contribute to the aging process, it is important to evaluate possible events that may lead to genomic instability as well as those linked to maintaining genome stability (Hoeijmakers 2009). Genotoxicity studies play an important role in the development of new drugs and should be carried out in the early stages of their development to identify potential genotoxic and/or carcinogenic activity and to assist in obtaining new, less toxic chemical structures. Thus, genotoxicity tests are used as a scan of the toxicological spectrum of natural or synthetic substances capable of producing genotoxic effects and assisting in the discovery of genoprotective substances for the everyday use of DNA mutation prevention (Aquino 2010, Niwa et al. 2013).

The comet assay is used to detect DNA damage. In this assay, the genetic material of the cell is fragmented using chemicals or radiation and then submitted to an electrophoresis process, so the fragmented DNA migrates over the agarose gel and the broken ends of the DNA molecule of negative charge become free to migrate in the electric field towards the anion, forming a structure similar to a comet. The length and amount of DNA in the comet's tail reflect damage to the genetic material (Fikrová et al. 2011).

Thus, the results when using the red propolis ethanolic extract demonstrated a genoprotective effect since when the means of the cell DNA damage indices (hepatocytes ZF-L) were compared in all the tested concentrations of the extract, no significant differences were observed in the negative control (sterile distilled water) (Table 2).

It was also found that the means of DNA damage at all tested concentrations of the red propolis ethanolic extract was significantly lower than the positive control (H2O2) mean, which is often used as a standard genotoxic substance in vitro exposure, enable to promote DNA fragmentation.

Table 1. Mean \pm standard deviation of phenol contents, total flavonoids and antioxidant activity of four samples of Apis mellifera red propolis obtained from the semiarid of Rio Grande do Norte, Brazil

\begin{tabular}{|c|c|c|c|c|}
\hline Sample & Geographic origin & $\begin{array}{c}\text { Total phenols } \\
(\mathrm{mg} \text { GAE/100g } \pm \mathrm{SD})\end{array}$ & $\begin{array}{c}\text { Total flavonoids } \\
(\mathrm{mg} \mathrm{QE} / 100 \mathrm{~g} \pm \mathrm{SD})\end{array}$ & $\begin{array}{c}\mathrm{RSA} \mathrm{IC}_{50} \\
(\mu \mathrm{g} / \mathrm{mL} \pm \mathrm{SD})\end{array}$ \\
\hline A & Parnamirim/RN & $141.07 \pm 1.27$ & $8.35 \pm 0.28$ & $61.04 \pm 0.31$ \\
\hline B & Parnamirim/RN & $120.41 \pm 1.13$ & $6.12 \pm 0.30$ & $54.14 \pm 1.50$ \\
\hline $\mathrm{C}$ & Mossoró/RN & $74.92 \pm 0.51$ & $2.42 \pm 0.17$ & $141.07 \pm 0.21$ \\
\hline $\mathrm{D}$ & Mossoró/RN & $86.09 \pm 0.47$ & $3.60 \pm 0.40$ & $129.10 \pm 0.49$ \\
\hline
\end{tabular}

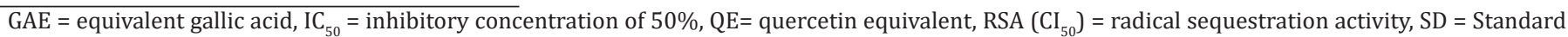
deviation. 
The percentages of genotoxicity reduction were $90.17 \pm 3.01$, $71.15 \pm 2.64$ and $43.07 \pm 4.99$, respectively, for the extract concentrations of 500,250 and $100 \mu \mathrm{l} / \mathrm{mL}$ (Table 3), proving the genoprotective effect of ethanolic extract of red propolis.

The literature often highlights that the biological properties of propolis are related to the presence of a variety of biologically active compounds, mainly phenolic compounds, which include flavonoids (Al Naggar et al. 2016). This finding fits in the red propolis analyzed in this study since in the evaluation of the chemical composition of the extract, high levels of phenolic compounds and flavonoids, and high antioxidant activity was found. Phenolic compounds have been reported to have genoprotective activity because of their antioxidant activity (Gontijo et al. 2014). Thus, the antioxidant activity of red propolis could be the possible explanation for genoprotective effect. The bioactive substances with antioxidant capacity in the extracted sample analyzed probably interacted with $\mathrm{H}_{2} \mathrm{O}_{2}$, blocking its deleterious effect on DNA, and exerting genoprotective activity. There are no studies in the literature evaluating the genoprotective effect of red propolis using a comet assay, highlighting the novelty of this study. The finding of the genoprotective effect on ZF-L hepatocyte lineage suggested that the red propolis obtained in Rio Grande do Norte may be able to assist in the prevention of diseases triggered by DNA damage.

\section{Antineoplastic activity assessment}

Although the studies and investments held in research, cancer chemotherapy still discourages scholars due to multiple drug resistance and serious side effects from morphological and physiological similarities between normal and transformed cells (Kamb 2005). Therefore, it is of great importance to identify natural molecules with potential therapeutic activity for future clinical studies and as a source of knowledge for the synthesis of new compounds with more effective and less toxic antitumor activity (Sawicka et al. 2012).

In vitro cytotoxicity tests are part of the initial screening to determine the possible antitumor potential of a natural product (Oliveira et al. 2012). The antineoplastic activity of the ethanolic extract of the red propolis of Rio Grande do Norte was evaluated by the human hepatocellular carcinoma cell line (HepG2) cytotoxicity assay, by the MTT test developed by Mosmann (1983) to estimate proliferation and cell survival.
The literature defined the assay as appropriate to estimate cytotoxicity quickly and accurately, and it is considered one of the most widely used tests by the National Cancer Institute (NCI) for its use in antineoplastic activity screening programs for anticancer drug screening (Oliveira et al. 2012). The test is based on the ability of succinate dehydrogenase, a Krebs cycle enzyme active in viable cell mitochondria, to convert the soluble and yellowish soluble water tetrazolium salt (MTT) into purple color formazan crystals. Thus, the amount of formazan measured by spectrophotometry is directly proportional to the number of viable cells (Porto et al. 2011).

Several in vitro and in vivo studies have demonstrated the antiproliferative potential of Brazilian propolis and its isolated constituents, and some results are favorable for its use (Miguel \& Antunes 2011, Salatino et al. 2011, Sforcin \& Bankova 2011, Cardinault et al. 2012). One of these studies is from Li et al. (2008), who showed that red propolis from northeastern Brazil exhibited antitumor potential, related to the presence of flavonoids and Pterocarpus. In the compounds evaluated, flavanone 7-hydroxy-6-methoxiflavanone and isoflavone mucronulatol showed a potent cytotoxic action against the lines of melanoma (B16-BL6), Lewis lung carcinoma (LLC), human pulmonary adenocarcinoma (A549), metastatic fibrosarcoma (HT-1080) and LLC, A549, respectively. In flavanones, the absence or presence of hydroxyl on carbon 3 (C-3) may be involved in the cytotoxic potential of these compounds. Regarding isoflavones, the increase in the number of methoxyl groups in the base structure necessarily increased the cytotoxic potential.

Also, Awale et al. (2008) evaluated the cytotoxic activity of methanolic extract of red propolis and some of its isolated compounds revealing that both the total extract and a pterocarpane (6aR, 11aR) -3,8-dihydroxy-9-methoxypterocarpane) showed high cytotoxicity against human pancreatic cancer cells (PANC-1). The mechanism of death is associated with a non-apoptotic time-dependent process that does not lead to deoxyribonucleic acid (DNA) fragmentation but necrotic morphological changes. The work by Frozza (2016) is also highlighted for finding a cytotoxic effect of the ethanol extract of red propolis from the states of Sergipe and Alagoas, against tumor cells of the Hep-2 strain. Based on this result, the authors concluded that red propolis became a promising candidate

Table 2. Mean \pm standard deviation of DNA damage indexes (idDNA), analyzed by comet assay for the assessment of the genoprotective effect of Apis mellifera red propolis ethanolic extract after liver cell exposure (hepatocytes ZF-L), for $2 \mathrm{~h}$ in three different concentrations of the extract, hydrogen peroxide $\left(\mathrm{H}_{2} \mathrm{O}_{2}\right)$ and sterile distilled water

\begin{tabular}{|c|c|c|c|c|c|}
\hline \multirow{2}{*}{ Parameter } & \multicolumn{3}{|c|}{ The concentration of ethanolic extract of red propolis $(\mu \mathrm{l} / \mathrm{mL})$} & \multirow{2}{*}{ Control + } & \multirow{2}{*}{ Control - } \\
\hline & 500 & 250 & 100 & & \\
\hline IdDNA & $8.15 \pm 2.05 a$ & $7.99 \pm 2.32 \mathrm{a}$ & $6.97 \pm 2.42 \mathrm{a}$ & $158.38 \pm 13.25 b$ & $7.80 \pm 2.32 \mathrm{a}$ \\
\hline
\end{tabular}

Table 3. Mean \pm standard deviation of the percentage reduction in genotoxicity analyzed by the comet assay for the evaluation of the genoprotective effect of the Apis mellifera red propolis ethanolic extract in ZF-L hepatocyte lineage, co-treated with three concentrations of propolis and hydrogen peroxide samples $\left(\mathrm{H}_{2} \mathrm{O}_{2}\right)$

\begin{tabular}{|c|c|c|c|}
\hline \multirow{2}{*}{ Parameter analyzed } & \multicolumn{3}{|c|}{ The concentration of ethanolic extract of red propolis $(\mu \mathrm{l} / \mathrm{mL})$} \\
\hline & 500 & 250 & 100 \\
\hline$\%$ genotoxicity reduction & $90.17 \pm 3.01$ & $71.15 \pm 2.64$ & $43.07 \pm 4.99$ \\
\hline
\end{tabular}


to inhibit cell growth and contributed to the different steps related to the carcinogenesis process.

As an antitumor activity parameter, the $\mathrm{NCI}$ in its anticancer drug screening program considers compounds with antineoplastic activity when they have $\mathrm{IC}_{50}<30 \mu \mathrm{g} / \mathrm{mL}$ (Itharat et al. 2004). The $\mathrm{IC}_{50}$ index = cytotoxicity index corresponding to the concentration reducing the number of cells to 50\%, the ethanolic extract of Rio Grande do Norte red propolis presented $\mathrm{IC}_{50}>500 \mu \mathrm{g} / \mathrm{mL}$ for the normal cell line (L929) and 358 $\mu \mathrm{g} / \mathrm{mL}$ for human liver cancer (HepG2) tumor cells. Doxorubicin as a reference drug showed cytotoxicity in all cell lines tested, with $\mathrm{IC}_{50}$ values ranging from $0.4818 \mu \mathrm{g} / \mathrm{mL}$ to $2.343 \mu \mathrm{g} / \mathrm{mL}$ for L929 and HepG2 strains, respectively (Table 4). Red propolis was not toxic to normal cells, even at the highest concentration tested $(500 \mu \mathrm{g} / \mathrm{mL})$. This fact may indicate safety for the use of the red propolis ethanolic extract.

\section{Serum biochemistry}

The evaluation of liver function in rodents (Rattus norvegicus Berkenhout, 1769), Wistar strain, in the different experimental groups in this study was the determination of serum biochemical parameters, which demonstrated that the mean values of AST enzyme were within normal limits for the species and did not differ significantly between G1, G2, and G3 when compared to each other. However, there was a significant increase in levels in G4 compared to the other groups. Regarding ALT serum levels, there was no significant difference between G1 and G2, and there was a significant increase in the mean values G3 and G4 than the other groups (Table 5).

The liver produces more than 60 transaminases, two of which are of major clinical importance, AST and ALT (Kwo et al. 2017). Their levels may cause liver damage because when liver cells are damaged or destroyed, these enzymes are released into the bloodstream, being sensitive indicators of liver damage (Hasan et al. 2013). Thus, the analysis of serum biochemical parameters confirmed the deleterious effect of TAA, considering that the mean values of these enzymes were significantly higher than the values in the other groups. The results obtained in the evaluation of the enzyme AST showed that its levels did not change in G1, G2, and G3, indicating that the administration of the red propolis ethanolic extract did not cause liver toxicity, and exerted hepatoprotective effect against the TAA-induced liver damage.

The hepatoprotective effect of red propolis obtained in Cuba was evaluated by Remirez et al. (1997) by induction of liver toxicity by the administration of $64 \mathrm{mg}$ of ethyl alcohol in mice, pretreated at the doses of 25,50 and $100 \mathrm{mg}$ of ethanolic extract of propolis. In the study, the authors found that in the propolis-treated group, there was a significant reduction in serum ALT levels and that the hepatoprotective effects of propolis were dose-dependent. The authors suggested that red propolis exerted a hepatoprotective effect due to its antioxidant properties, which exerted free radical scavenging effects, capable of promoting deleterious effects on the liver. Harrizul et al. (2018) also observed a reduction in serum enzyme indicating ALT liver damage, and a reduction in liver cell degeneration scores and inflammatory reaction in pre-treated rodents with $280 \mathrm{mg} / \mathrm{kg}$ of propolis obtained in Indonesia, which were experimentally submitted to hepatic damage induced by hepatotoxic drug valproic acid at a dose of $350 \mathrm{mg}$.

Regarding the mean values of serum albumin and total protein levels, the values were also within the normal range for the species, and no significant difference was observed between G1, G2, and G3. In G4 there was a significant reduction in values (Table 5). Measurements of albumin and total proteins are also markers often used as a test of liver function since most plasma proteins are produced exclusively by the liver (Schinoni 2006). Thus, this result could also indicate

Table 4. Inhibitory concentration values $\left(\mathrm{IC}_{50}\right)$ promoted by the ethanolic extract of Apis mellifera red propolis and doxorubicin chemotherapy against cell lines L929 and HepG2 by MTT after 72h exposure

\begin{tabular}{ccc}
\hline Compounds & \multicolumn{2}{c}{$\mathrm{CI}_{50}$ Cell lines $\mu \mathrm{G} / \mathrm{mL}^{*}$} \\
\cline { 2 - 3 } & $\mathrm{L} 929$ & $\mathrm{HepG} 2$ \\
\hline Hydroethanolic extract of red propolis & $>500 \mu \mathrm{g} / \mathrm{mL}$ & $358 \mu \mathrm{g} / \mathrm{mL}$ \\
Doxorubicin & $0.4818 \mu \mathrm{g} / \mathrm{mL}$ & $2.343 \mu \mathrm{g} / \mathrm{mL}$ \\
\hline
\end{tabular}

*Values of three independent experiments and presented in $\mathrm{IC}_{50}$ values obtained by nonlinear regression with $95 \%$ confidence interval.

Table 5. Mean \pm standard deviation values of serum biochemical parameters in rodents (Rattus norvegicus Berkenhout, 1769), Wistar strain in experimental groups G1 (control), G2 (treated with ethanolic extract of red propolis), G3 (treated with ethanolic extract of propolis TA4), G4 (TAA-treated) and reference values

\begin{tabular}{|c|c|c|c|c|c|}
\hline \multirow{2}{*}{ Parameters } & \multicolumn{4}{|c|}{ Experimental groups } & \multirow{2}{*}{ Reference } \\
\hline & G1 & G2 & G3 & G4 & \\
\hline AST (U/L) & $97.14 \pm 4.77 \mathrm{a}$ & $108.33 \pm 8.38 \mathrm{a}$ & $114.22 \pm 7.31 \mathrm{a}$ & $184.7 \pm 19.87 \mathrm{~b}$ & $131.33 \pm 43.98$ \\
\hline ALT (U/L) & $62.16 \pm 20.21 \mathrm{a}$ & $67.99 \pm 11.72 a$ & $114.7 \pm 15.35 b$ & $120.79 \pm 12.71 b$ & $57.55 \pm 11.95$ \\
\hline ALB (g/dL) & $2.41 \pm 0.3 \mathrm{a}$ & $2.23 \pm 0.17 \mathrm{a}$ & $2.1 \pm 0.49 \mathrm{a}$ & $1.6 \pm 0.61 b$ & $2.65 \pm 0.30$ \\
\hline $\mathrm{TP}(\mathrm{g} / \mathrm{dL})$ & $6.88 \pm 0.61 \mathrm{a}$ & $6.80 \pm 0.30 \mathrm{a}$ & $5.11 \pm 0.5 \mathrm{a}$ & $3.71 \pm 0.46 b$ & $5.75 \pm 0.87$ \\
\hline BILT (mg/dL) & $0.09 \pm 0.01 \mathrm{a}$ & $0.11 \pm 0.02 \mathrm{a}$ & $0.10 \pm 0.01 \mathrm{a}$ & $0.30 \pm 0.05 b$ & $0.02 \pm 0.18 c$ \\
\hline GLUC (mg/dL) & $120.9 \pm 16.14 \mathrm{a}$ & $114.14 \pm 17.03 a$ & $127.57 \pm 30.63 a$ & $117.80 \pm 3.0 \mathrm{a}$ & $138.72 \pm 30.1 b$ \\
\hline TRIG (mg/dL) & $47.4 \pm 10.93 a$ & $42.82 \pm 12.14 \mathrm{a}$ & $41.2 \pm 10.36 \mathrm{a}$ & $40.82 \pm 7.0 \mathrm{a}$ & $46.87 \pm 18.73 a$ \\
\hline
\end{tabular}

AST = aspartate aminotransferase, ALT = alanine aminotransferase, ALB = albumin, TP = total protein, BILT = total bilirubin, GLUC = glucose, TRIG = triglycerides; a,b,c = Means on the same line followed by equal letters are statistically equal, paired Student's t-test, \# Wilcoxon test ( $\mathrm{p}<0.05$ ). 
absence of red propolis hepatotoxicity, as well as underlines its hepatoprotective effect.

This study also showed the significant increase in serum bilirubin levels in G4, while in G1, G2, and G3 the values remained within the normal range for the species and did not differ from each other. No significant differences in mean glucose and triglyceride values were observed between the experimental groups (Table 5). The assessment of serum bilirubin levels can diagnose or monitor liver diseases such as cirrhosis, hepatitis or biliary obstruction (Thapa \& Walia 2007). Bilirubin is a byproduct of hemoglobin metabolism in the liver, and when there is excess of this substance in the blood, it is a sign that it is not properly metabolized by the liver (Martelli 2012). Thus, the permanence of serum bilirubin values in $G 1, G 2$, and $G 3$ could reinforce the absence of hepatotoxicity and the hepatoprotective effect of red propolis from Rio Grande do Norte.

\section{Macroscopic and histological assessment}

In the macroscopic examination of the livers collected at the end of the experimental period, the animals of G1 and G2 had a liver with the morphological aspect within the normal range observed for the species, without evidence of changes in shape, color, and consistency (Fig.1A,B). However, the animals from Groups G3 and G4 developed cirrhosis. The livers of the animals of G3 presented surface containing small nodules flush with the organ surface and thin capsule, and relatively soft consistency and whitish-yellow color (Fig.1C). The livers of the animals from G4 showed evidence of evolution of severe cirrhosis, characterized by the presence of large regenerative nodules on the surface, thickened capsule, hardened and cut resistant consistency, and brownish coloration (Fig.1D).

In a histopathological assessment performed on hematoxylin-eosin (HE) stained slides, the liver tissue of the animals from G1 and G2 had no changes, showing normal histological appearance (Fig.2A,B). In the liver of G3 animals, hepatocyte necrosis was observed, characterized by the presence of cells with a pycnotic nucleus, in cariorrexia and cytoplasmic acidophilia. Hepatocyte necrosis was more evident in the central lobular and periportal regions. Isolated foci of hepatocyte hyperplasia, discrete connective tissue deposition around the central lobular vein, as well as thin connective tissue septa involving hepatocyte nodules and moderate bile duct hyperplasia (Fig.2C) were also found. The histological changes were more severe in the liver of G4 animals, with the presence of large regenerative nodules of hepatocytes surrounded by thick bridges of connective tissue, and deposition of connective tissue in the periportal
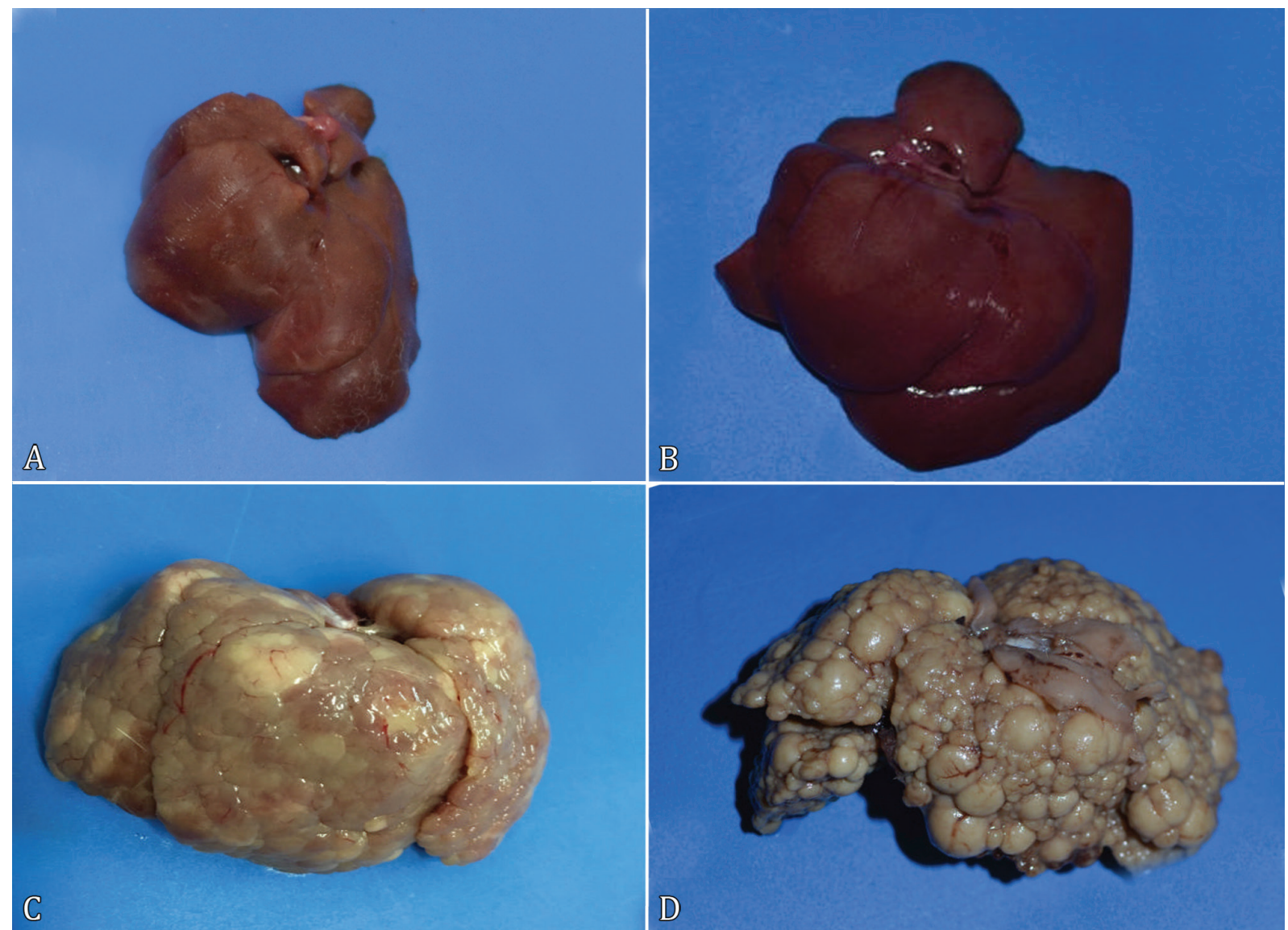

Fig.1. (A) Rodent liver Rattus norvegicus, Wistar strain, Group G1, control, with normal morphological aspects. (B) Rodent liver Rattus norvegicus, Wistar strain, group G2, treated with ethanolic extract of red propolis, with normal morphological aspects. (C) Cirrhotic rodent liver, Rattus norvegicus, Wistar strain, group G3, with small regenerative nodules flush with the surface. G3 rodents were treated with ethanolic extract of red propolis and thioacetamide. (D) Rodent cirrhotic liver, Rattus norvegicus, Wistar strain, group G4, with large regenerative nodules on the surface. G4 rodents were treated with thioacetamide. 
region and around the central-lobular vein and moderate bile duct hyperplasia (Fig.2D).

Big advances in understanding the mechanisms responsible for hepatotoxic damage have emerged from in vitro or in vivo model studies. Such models also allowed proving the therapeutic and toxic potentialities of drugs or natural products. Pathological damage caused by hepatotoxins in experimental models may be similar to the damage that occurs in different animal and human liver diseases (Yogalakshmi et al. 2010). Several animal models reproduce both surgical and chemical liver damage. Chemical procedures are developed through the administration of hepatotoxic substances. Among several experimental models of cirrhosis induction, TAA, a drug originally used as a fungicide to protect oranges against deterioration and later recognized as a potent hepatotoxin, has been the most promising because it produces macroscopic and histological morphological patterns similar to cirrhosis in human beings (Passos et al. 2010).

The study of the hepatotoxic and hepatoprotective potential of a drug or natural products can be assessed by diagnosing liver lesions, by studying changes in serum biochemical profile, and can be confirmed by anatomopathological examination of the liver (Garcia et al. 2004b).

Thus, elevated levels of AST, ALT, and bilirubin in the blood together with liver histological changes such as hepatocyte degeneration, necrosis and hyperplasia, and fibrosis are indicators of AAT-induced hepatocellular damage. In the livers of animals of the group treated with TAA (G4), a loss of the organ architectural pattern was observed, with the presence of regenerative nodules characteristic of cirrhosis. Cirrhosis is the scar response of the liver in most chronic or advanced inflammatory liver diseases, which is anatomically defined
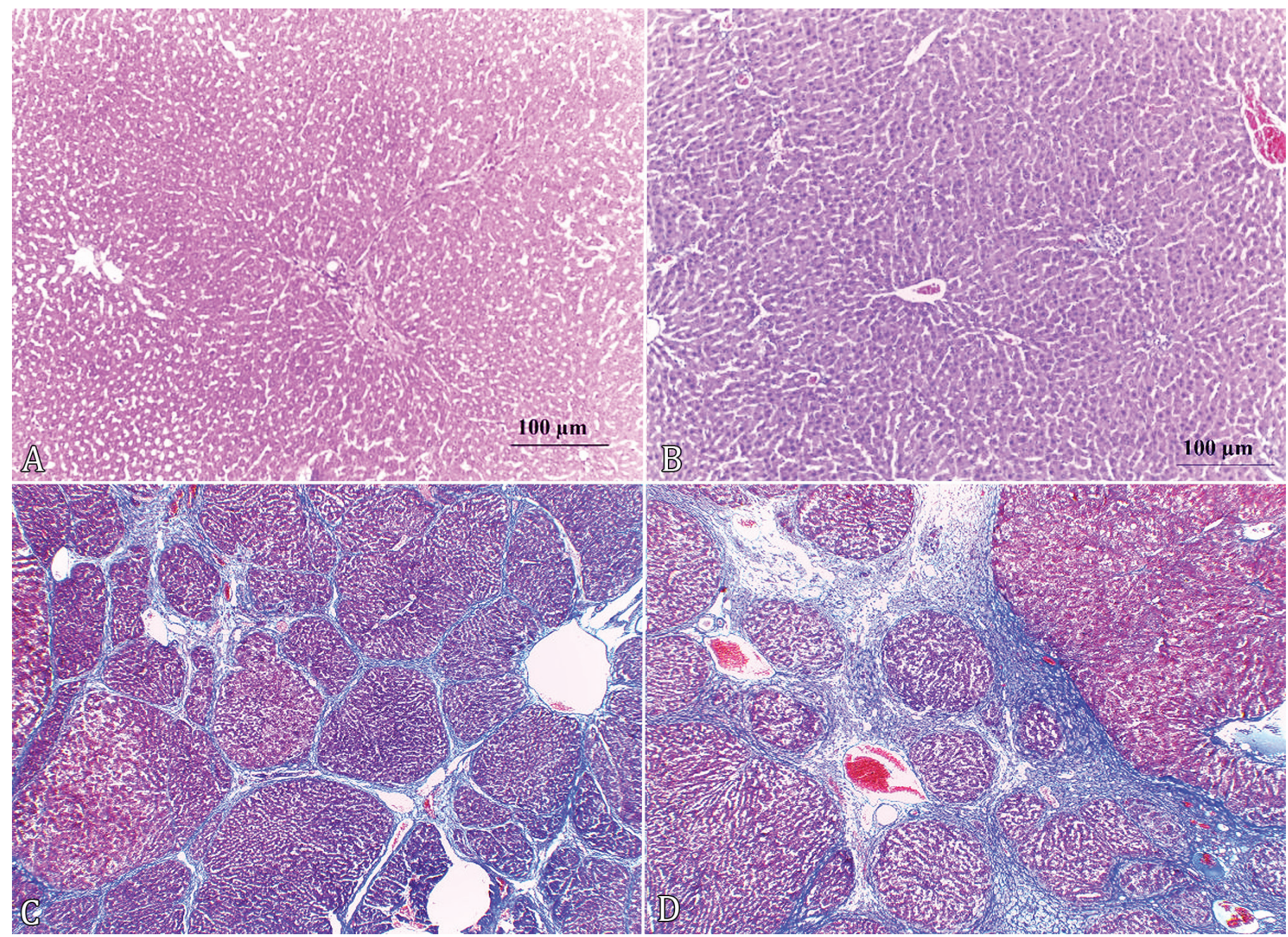

Fig.2. (A) Rodent liver Rattus norvegicus, Wistar strain, Group G1, control, with normal histological appearance. HE, obj.20x. (B) Rodent liver Rattus norvegicus, Wistar strain, Group G2, treated with ethanolic extract of red propolis, with normal histological appearance. Gomori's trichrome, obj.20x. (C) Rodent liver, Rattus norvegicus, Wistar strain, from Group G3, with regenerative nodules surrounded by thin connective tissue septa. G3 rodents were treated with ethanolic extracts of propolis and thioacetamide. HE, obj.20x. (D) Rodent liver, Rattus norvegicus, Wistar strain, Group G4, with regenerative nodules surrounded by thick fibrous connective tissue septa. G4 rodents were treated with thioacetamide. HE, obj.20x. 
as a diffuse process of fibrosis and nodule formation, often accompanied by hepatocellular necrosis (Brandão et al. 2006).

Thus, the results of the evaluation of the hepatoprotective effect of red propolis of Rio Grande do Norte are promising, in the reduction of liver damage experimentally induced by hepatotoxic substances. The macroscopic and histological evaluation of the livers of G3 animals showed that the red propolis ethanolic extract had a hepatoprotective effect, reducing the severity of cirrhosis because the characteristic regenerative nodules of cirrhosis were smaller and more discreet when compared to G4 animals. In G3 animals, the connective tissue deposition was less intense, and the septa surrounding the regenerative nodules were thin and little evident (Fig.2C).

\section{Liver weight}

The parameter of the liver weight was statistically similar between G1 and G2. There was a significant increase in liver weight in G3 and G4 compared to the other groups (Table 6). The increase in liver weight in G3 and G4 than in the other groups is probably related to the pathological characteristic aspects of cirrhotic liver tissue. The main pathological processes that occur in cirrhosis are cell fibrosis, regeneration, or proliferation (Ivanova 2016), so liver hypertrophy often occurs as observed in the livers of animals from G3 and G4.

\section{Stereological analysis}

Liver tissue analysis in the different experimental groups by stereology showed that there was no statistical difference between the percentage of hepatocytes in G1 and G2. However, the percentage of hepatocytes in G4 decreased significantly compared to the other groups, while the percentage of hepatocytes in G3 did not differ from G1, G2. There was also a significant reduction in the percentage of sinusoids in G4, whereas, in G1, G2 and G3 did not differ significantly. Regarding the percentage of collagen in the liver tissue samples, there was no significant difference in G1 and G2. In G3 and G4, there was a significant increase in the percentage of collagen and a significant difference than the other groups (Table 7).
This study sought to analyze the histological images of liver tissue by the stereological method. This method can determine three-dimensional quantitative parameters of anatomical structures from two-dimensional histological sections. Stereology is a tool that provides excellent results as it provides reliable data for quantitative analysis of the material of histological origin (Ochs 2006). This method helps to verify the histological changes of the livers of rodents in the different experimental groups. Therefore, the reduction in the percentage of G4 hepatocytes may be attributed to the detrimental effect of TAA on these cells, while the increase in the percentage of hepatocytes in G3 relative to G4 may indicate that the red propolis ethanolic extract protected the hepatocytes from the TAA deleterious effect or possibly the ethanolic extract of red propolis may have contributed to the regeneration of damaged hepatocytes.

Hepatocytes are the main parenchymal cells of the liver and are capable of performing almost all functions assigned to this organ, considered as the most multifunctional cell in the body (Harzer et al. 2015). Thus, the absence of statistical difference in the percentage of hepatocytes in G3 than in G1 and G2 and significant increase than in G4 may indicate a morphological improvement that may result in a functional liver improvement, confirming once again the hepatoprotective effect of the ethanolic extract of red propolis.

Changes in the percentage of sinusoids also reflect the histological changes in the liver tissue of rodents submitted to different experimental protocols. Hepatic sinusoids are capillaries or channels located in the space between the hepatocyte cords, in which blood passes to reach the terminal hepatic vein. Its walls are lined with fenestrated endothelial cells that expose hepatocytes directly to a series of hormones, growth factors, and nutrients that have hepatotropic action (Jesus et al.2000). The significant reduction in the percentage of sinusoids in G4 can be explained by the establishment of the most intense fibrosis in this group. According to Bedossa et al. (2003), the death of hepatocytes leads to fibrosis repair, with deposition of fibrous tissue, which will occur around the sinusoid vessels, causing obliterative fibrosis, which may result in compromised intrahepatic blood and biliary flow. This set of characteristics reduces blood contact with hepatocytes,

Table 6. Mean \pm standard deviation values of rodent's liver weight (Rattus norvegicus Berkenhout, 1769), Wistar strain in experimental groups G1 (control), G2 (treated with ethanolic extract of red propolis), G3 (treated with ethanolic extract of red propolis and TAA) and G4 (TAA treated)

\begin{tabular}{|c|c|c|c|c|}
\hline \multirow{2}{*}{ Variable } & \multicolumn{4}{|c|}{ Experimental groups } \\
\hline & G1 & G2 & G3 & G4 \\
\hline Weight (g) & $10.05 \pm 2.74 \mathrm{a}$ & $8.73 \pm 0.64 a$ & $15.98 \pm 1.9 b$ & $17.01 \pm 0.89 b$ \\
\hline
\end{tabular}

Table 7. Mean \pm standard deviation values of stereological parameters of rodent liver (Rattus norvegicus Berkenhout, 1769), Wistar strain, in experimental groups G1 (control), G2 (treated with ethanolic extract of red propolis), G3 (treated with ethanolic extract of red propolis and TAA) and G4 (treated with TAA)

\begin{tabular}{crrrr}
\hline \multirow{2}{*}{ Variables (\%) } & \multicolumn{4}{c}{ Experimental groups } \\
\cline { 2 - 5 } & G1 & G2 & G3 & G4 \\
\hline Hepatocytes & $77.64 \pm 5.91 \mathrm{a}$ & $77.47 \pm 3.18 \mathrm{a}$ & $64.60 \pm 0.50 \mathrm{ab}$ & $55.68 \pm 3.70 \mathrm{~b}$ \\
Sinusoids & $19.01 \pm 5.01 \mathrm{a}$ & $18.02 \pm 5.31 \mathrm{a}$ & $17.29 \pm 8.48 \mathrm{a}$ & $9.78 \pm 4.78 \mathrm{~b}$ \\
Collagen & $3.35 \pm 1.49 \mathrm{a}$ & $4.45 \pm 4.78 \mathrm{a}$ & $18.11 \pm 7.98 \mathrm{~b}$ & $34.54 \pm 5.22 \mathrm{c}$
\end{tabular}

$\overline{a, b, c}=$ Means on the same line followed by equal letters are statistically equal, paired Student's t-test, \# Wilcoxon test ( $p<0.05)$. 
which can affect the availability of hepatocyte nutrients and hepatotrophic factors and impair their function.

Changes in collagen percentages may also be related to the pathological features of cirrhotic liver tissue since the literature conceptualizes cirrhosis as the final phase of chronic liver damage in response to direct aggression or inflammation, with a large number of fibrous tissue forms, specifically collagen fibers deposited, thus the significant increase in collagen in G4 clearly reflects this condition. The significant reduction in the percentage of G3 collagen than in G4 also reflects the hepatoprotective effect of ethanolic extract of red propolis from Rio Grande do Norte, reducing hepatocyte damage, reparative fibrosis, and maintenance of the histological pattern close to observed in normal liver tissue, as found in Groups G1 and G2.

\section{CONCLUSIONS}

The hepatoprotective effect of red propolis was found in Wistar rodents (Rattus norvegicus), treated with $500 \mathrm{mg} / \mathrm{kg}$ of ethanolic propolis extracts and experimentally submitted to induction of cirrhosis by TAA, since the results of serum levels of the enzymes indicating liver damage showed that the ethanolic extract did not cause liver toxicity and exerted hepatoprotective effect.

Changes indicating cirrhosis were less significant in macroscopic and histological evaluations in animals treated with propolis extract. In vitro, the extract promoted genoprotective effect by reducing DNA damage in liver cells damaged by $\mathrm{H}_{2} \mathrm{O}_{2}$, as well as exerting no cytotoxic effect on normal cells (L929), showing antineoplastic activity in human hepatocellular carcinoma cell line (HepG2), in which the red propolis is a promising candidate to inhibit cell growth and contribute to the different steps related to the carcinogenesis process.

Conflict of interest statement.- The authors have no competing interests.

\section{REFERENCES}

Aguiar G.R., Lemos T.L.G., Dornelas C.A., Silva A.M., Almeida M.C.S., Ferreira D.A., Monte F.J.Q., Braz Filho R., Oliveira I.R. \& Nascimento P.G.G. 2018. Estudo químico e avaliação biológica da própolis vermelha de Alagoas. Revta Virtual Quím. 10(1):1-11.

Ahn M., Kumazawa S., Usui Y., Nakamura J., Matsuka M., Zhu F. \& Nakayama T. 2007. Antioxidant activity and constituents of propolis collected in various areas of China. Food Chem. 101(4):1383-1392. <http://dx.doi. org/10.1016/j.foodchem.2006.03.045>

Al Naggar Y., Sun J., Robertson A., Giesy J.P. \& Wiseman S. 2016. Chemical characterization and antioxidant properties of Canadian própolis. J. Apic. Res. 55(4):305-314.<http://dx.doi.org/10.1080/00218839.2016.1233700>

Amin Z.A., Bilgen M., Alshawsh M.A., Ali H.M., Hadi A.H.A. \& Abdulla M.A. 2012. Protective role of Phyllanthus niruri extract against thioacetamide induced liver cirrhosis in rat model. Evid. Based Complement. Alternat. Med. 241583:1-9. <http://dx.doi.org/10.1155/2012/241583><PMid:22649471>

Andrade G.B., Montes G.S., Conceição G.M. \& Saldiva P.H. 1999. Use of the Picrosirius-polarization method to age fibrotic lesions in the hepatic granulomas produced in experimental murine schistosomiasis. Ann. Trop. Med. Parasitol. 93(3):265-272. <http://dx.doi.org/10.1080/00034983.1 999.11813422><PMid:10562828>

Aquino I. 2010. Efeito genotóxico da artemisinina e do artesunato em células de mamíferos. Master's Thesis, Universidade Estadual Paulista, Botucatu, SP. 81p.
Araújo K.S.S., Santos Júnior J.F., Sato M.O., Finco F.D.B.A., Soares I.M., Barbosa R.S., Alvim T.C., Ascêncio S.D. \& Mariano S.M.B. 2016. Physicochemical properties and antioxidant capacity of propolis of stingless bees (Meliponinae) and Apis from two regions of Tocantins, Brazil. Acta Amaz. 46(1):61-68. <http://dx.doi.org/10.1590/1809-4392201501045>

Awale S., Li F., Onozuka H., Esumi H., Tezuka Y. \& Kadota S. 2008. Constituents of Brazilian red propolis and their preferential cytotoxic activity against human pancreatic PANC-1 cancer cell line in nutrient-deprived condition. Bioorg. Med. Chem. 16(1):181-189. <http://dx.doi.org/10.1016/j. bmc.2007.10.004><PMid:17950610>

Bankova V. 2005. Recent trends and important developments in propolis research. Evid. Based Complement. Alternat. Med. 2(1):29-32. <http:// dx.doi.org/10.1093/ecam/neh059> <PMid:15841275>

Bedossa P., Dargère D. \& Paradis V. 2003. Sampling variability of liver fibrosis in chronic hepatitis C. Hepatology, Baltimore, 38(6):1449-1457. <http:// dx.doi.org/10.1053/jhep.2003.09022><PMid:14647056>

Brandão D.F., Ramalho L.N., Ramalho F.S., Zucoloto S., Martinelli A.L. \& Silva O.C. 2006. Liver cirrhosis and hepatic stellate cells. Acta Cir. Bras. 21(Suppl.1):54-57.<http://dx.doi.org/10.1590/S0102-86502006000700013> <PMid:17013515>

Bueno-Silva B., Alencar S.M., Koo H., Ikegaki M., Silva G.V., Napimoga M.H. \& Rosalen P.L. 2013. Anti-inflammatory and antimicrobial evaluation of neovestitol and vestitol isolated from Brazilian red propolis. J. Agric. Food. Chem. 61(19):4546-4550. <http://dx.doi.org/10.1021/jf305468f> <PMid:23607483>

Cardinault N., Cayeux M.O. \& Du Sert P.P. 2012. La propolis: origine, composition et propriétés. Phytothérapie 10(5):298-304.<http://dx.doi.org/10.1007/ s10298-012-0733-y>

Carratù E. \& Sanzini E. 2005. Sostanze biologicamente attive presenti negli alimenti di origine vegetable. Ann. Ist. Super. Sanità 41(1):7-16. <PMid:16037643>

Daleprane J.B. \& Abdalla D.S. 2013. Emerging roles of propolis: antioxidant, cardioprotective, and antiangiogenic actions. Evid. Based Complement. Alternat. Med. 2013(1):1-8. <http://dx.doi.org/10.1155/2013/175135> <PMid:23662115>

Fikrová P., Stětina R., Hronek M., Hyšpler R., Tichá A. \& Zadák Z. 2011. Application of the comet assay method in clinical studies. Wien. Klin. Wochenschr. 123(23/24):693-699. <http://dx.doi.org/10.1007/s00508011-0066-0><PMid:22024999>

Freitas M.O., Ponte F.A.F., Lima M.A.S. \& Silveira E.R. 2008. Flavonoids and Triterpenes from the nest of the stingless bee Trigona spinipes. J. Braz. Chem. Soc. 19(3):532-535. <http://dx.doi.org/10.1590/S0103$50532008000300022>$

Frozza C.O., Garcia C.S., Gambato G., de Souza M.D., Salvador M., Moura S., Padilha F.F., Seixas F.K., Collares T., Borsuk S., Dellagostin O.A., Henriques J.A. \& Roesch-Ely M. 2013. Chemical characterization, antioxidant and cytotoxic activities of Brazilian red propolis. Food. Chem. Toxicol. 52:137142. <http://dx.doi.org/10.1016/j.fct.2012.11.013><PMid:23174518>

Frozza C.O.S. 2016. Avaliação dos efeitos antitumorais da própolis vermelha em células humanas in vitro. Doctoral Dissertation, Universidade de Caxias do Sul, Caxias do Sul, RS. 125p.

Garcia R.C., Sá M.E.P., Langoni H. \& Funari S.R.C. 2004a. Efeito do extrato alcoólico de própolis sobre a Pasteurella multocida "in vitro". Acta Scient., Anim. Sci. 26(1):69-77. <http://dx.doi.org/10.4025/actascianimsci. v26i1.1952>

Garcia R.C., Sá M.E.P., Langoni H. \& Fenari S.R.C. 2004b. Efeito do extrato alcoólico de própolis sobre o perfil bioquímico e o desempenho de coelhas jovens. Acta Scient., Anim. Sci. 26(1):57-67.<http://dx.doi.org/10.4025/ actascianimsci.v26i1.1950>

Gontijo D.C., Fietto L.C. \& Leite J.P.V. 2014. Avaliação fitoquímica e atividade antioxidante, antimutagênica e toxicológica do extrato aquoso das folhas de 
Ocimum gratissimum L. Revta Bras. Plantas Med. 16(4):874-880. <http:// dx.doi.org/10.1590/1983-084X/12_002>

Grand A.A., Vennat B., Pourrat A. \& Legret P. 1994. Standardization of propolis extract and identification of principal constituents. J. Pharm. Belg. 49(6):462-468. <PMid:7884635>

Harrizul R., Almahdy, Nur A. \& Helmi A. 2018. Propolis hepatoprotector effect on liver damage of white mice induced by valproic acid. Int. J. Pharm. Sci. Med. 3(8):1-12.

Harzer B., Stipp M.C. \& Herrerias T. 2015. Avaliação da função hepática de peixes Rhamdia quelen expostos aos desreguladores endócrinos estriol e estrona. Revinter 8(1):82-99. <http://dx.doi.org/10.22280/revintervol8ed1.195>

Hasan M., Hyder M.A. \& Mohieldein A.H. 2013. Comparative levels of ALT, AST, ALP and GGT in liver associated diseases. Eur. J. Exp. Biol. 3(2):280-284.

Hatano A., Nonaka T., Yoshino M., Ahn M.R., Tazawa S., Araki Y. \& Kumazawa S. 2012. Antioxidant activity and phenolic constituents of red propolis from Shandong, China. Food Sci. Technol. Res. 18(4):577-584. <http:// dx.doi.org/10.3136/fstr.18.577>

Hoeijmakers J.H. 2009. DNA damage, aging, and cancer. N. Engl. J. Med. 361(15):1475-1485. <http://dx.doi.org/10.1056/NEJMra0804615> <PMid:19812404>

Horst M.A. \& Lajolo F.M. 2012. Biodisponibilidade de compostos bioativos de alimentos, p.879-914. In: Cozzolino S.M.F. (Ed), Biodisponibilidade de Nutrientes. Vol.1. 4th ed. Manole, Barueri.

Itharat A., Houghton P.J., Eno-Amooquaye E., Burke P.J., Sampson J.H. \& Raman A. 2004. In vitro cytotoxic activity of Thai medicinal plants used traditionally to treat cancer. J. Ethnopharmacol. 90(1):33-38. <http:// dx.doi.org/10.1016/j.jep.2003.09.014> <PMid:14698505>

Ivanova I. 2016. Liver cirrhosis: new concepts. Scripta Scient. Med. 48(2):9-16.

Jesus R.P., Waitzberg D.L. \& Campos F.G. 2000. Regeneração hepática: papel dos fatores de crescimento e nutrientes. Revta Assoc. Med. Bras. 46(3):242254. <http://dx.doi.org/10.1590/S0104-42302000000300010>

Kamb A. 2005. What's wrong whith our cancer models? Nat. Rev. Drug. Discov. 4(2):161-165. <http://dx.doi.org/10.1038/nrd1635><PMid:15688078>

Kwo P.Y., Cohen S.M. \& Lim J.K. 2017. ACG clinical guideline: evaluation of abnormal liver chemistries. Am. J. Gastroenterol. 112(1):18-35. <http:// dx.doi.org/10.1038/ajg.2016.517><PMid:27995906>

Li F., Awale S., Tezuka Y. \& Kadota S. 2008. Cytotoxic constituents from Brazilian red propolis and their structure-activity relationship. Bioorg. Med. Chem. 16(10):5434-5440. <http://dx.doi.org/10.1016/j.bmc.2008.04.016> <PMid:18440233>

Lima M.G. 2006. A Produção de Própolis no Brasil. São Sebastião Editora e Gráfica, São João da Boa Vista. 120p.

Lopes M.A. 2014. Qualidade dos produtos apícolas da Guiné Bissau: mel e própolis. Master's Thesis, Universidade de Salamanca, Bragança. 91p.

Lovell M.A., Gabbita S.P. \& Markesbery W.R. 1999. Increased DNA oxidation and decreased levels of repair products in Alzheimer's disease ventricular CSF. J. Neurochem. 72(2):771-776. <http://dx.doi. org/10.1046/j.1471-4159.1999.0720771.x><PMid:9930752>

Lustosa S.R., Galindo A.B., Nunes L.C.C., Randau K.P. \& Rolim Neto P.J. 2008. Própolis: atualizações sobre a química e a farmacologia. Revta Bras. Farmacogn. 18(3):447-454. <http://dx.doi.org/10.1590/S0102695X2008000300020>

Mahmoud U.T., Abdel-Rahman M.A., Darwish M.H.A., Applegate T.J. \& Cheng H. 2015. Behavioral changes and feathering score in heat stressed broiler chickens fed diets containing different levels of própolis. Appl. Anim. Behav. Sci. 166:98-105. <http://dx.doi.org/10.1016/j.applanim.2015.03.003>

Marcos R., Monteiro R.A. \& Rocha E. 2012. The use of design-basead stereology to evaluate volumes and number in the liver: a review with practical guidelines. J.
Anat. 220(4):303-317.<http://dx.doi.org/10.1111/j.1469-7580.2012.01475. $\mathrm{x}><$ PMid:22296163>

Martelli A. 2012. Síntese e metabolismo da bilirrubina e fisiopatologia da hiperbilirrubinemia associados à Síndrome de Gilbert: revisão de literatura. Revta Med. Minas Gerais 22(2):216-220.

Melo J.G., Araújo T.A.S., Castro V.T.N.A., Cabral D.L.V., Rodrigues M.D., Nascimento S.C., Amorim E.L.C. \& Albuquerque U.P. 2010. Antiproliferative activity, antioxidant capacity and tannin content in plants of semi-arid northeastern Brazil. Molecules 15(12):8534-8542. <http://dx.doi.org/10.3390/ molecules15128534><PMid:21107308>

Mensor L.L., Menezes F.S., Leitão G.G., Reis A.S., Santos T.C., Coube C.S. \& Leitão S.G. 2001. Screnning of Brazilian plant extracts for antioxidant activity by the use of DPPH free radical method. Phytother. Res. 15(2):127-130. <http://dx.doi.org/10.1002/ptr.687> <PMid:11268111>

Mezzalira B., Funchal C. \& Dani C. 2014. Ensaio cometa: avaliação da atividade dos calcogênio. Ciênc. Mov. 2(33):47-55. <http://dx.doi.org/10.15602/19839480/cmbs.v16n33p47-55>

Miguel M.G. \& Antunes M.D. 2011. Is propolis safe as an alternative medicine? J. Pharm. Bioall. Sci. 3(4):479-495. <http://dx.doi.org/10.4103/09757406.90101><PMid:22219581>

Mosmann T. 1983. Rapid colorimetric assay for cellular growth and survival: application to proliferation and cytotoxicity assays. J. Immunol. Methods 65(1/2):55-63. <http://dx.doi.org/10.1016/0022-1759(83)90303-4> <PMid:6606682>

Niwa A.M., Oliveira R.J. \& Mantovani M.S. 2013. Evaluation of the mutagenicity and antimutagenicity of soy phytoestrogens using micronucleus and comet assays of the peripheral blood of mice. Genet. Mol. Res. 12(1):519-527. <http://dx.doi.org/10.4238/2013.February.27.1><PMid:23512669>

Nunes C.A. \& Guerreiro M.C. 2012. Characterization of Brazilian green propolis throughout the seasons by headspace GC/MS and ESI-MS. J. Sci. Food Agric. 92(2):433-438. <http://dx.doi.org/10.1002/jsfa.4596><PMid:21918994>

Ochs M. 2006. A brief update on lung stereology. J. Microsc. 222(3):188-200. <http://dx.doi.org/10.1111/j.1365-2818.2006.01587.x><PMid:16872418>

Oldoni T.L.C., Oliveira S.C., Andolfatto S., Karling M., Calegari M.A., Sado R.Y., Maia F.M.C., Alencar S.M. \& Lima V.A. 2015. Chemical characterization and optimization of the extraction process of bioactive compounds from propolis produced by selected bees Apis mellifera. J. Braz. Chem. Soc. 26(10):2054-2062.

Oliveira C.R., Menezes A.C.S., Moraes M.O., Vieira L.M., Pereira A.G., Lima R.S. \& Santos M.L. 2012. Avaliação citotóxica em três linhagens de células tumorais das frações obtidas da casca do caule de Salacia crassifolia (MART. ex. Schult.) G. Dom. (Celastraceae). Revta Colomb. Ciênc. Quím. Farm. 41(2):133-142.

Passos C.C., Ferreira A.O., Blazquez F.J.H. \& Guerra R.R. 2010. Modelos experimentais para indução de cirrose hepática em animais: revisão de literatura. Biotemas 23(2):183-190.

Piccinelli A.L., Campo Fernandez M., Cuesta-Rubio O., Márquez Hernández I., De Simone F. \& Rastrelli L. 2005. Isoflavonoids isolated from Cuban propolis. J. Agric. Food Chem. 53(23):9010-9016. <http://dx.doi.org/10.1021/ jf0518756><PMid:16277396>

Pinheiro M.S. 2009. Avaliação da atividade antimicrobiana e citoprotetora gástrica dos extratos de mangaba, caju e própolis vermelha. Master's Thesis, Universidade Tiradentes, Aracaju, SE. 70p.

Porto I.C., Oliveira D.C., Raele R.A., Ribas K.H., Montes M.A. \& Castro C.M 2011. Cytotoxicity of current adhesive systems: in vitro testing on cell cultures of primary murine macrophages. Dent. Mater. 27(3):221-228. <http:// dx.doi.org/10.1016/j.dental.2010.10.006><PMid:21074251>

Remirez D., González R., Rodriguez S., Ancheta O., Bracho J.C., Rosado A., Rojas E. \& Ramos M.E. 1997. Protective effects of propolis extract on allyl 
alcohol-induced liver injury in mice. Phytomedicine 4(4):309-314. <http:// dx.doi.org/10.1016/S0944-7113(97)80038-4><PMid:23195579>

Salatino A., Fernandes-Silva C.C., Righi A.A. \& Salatino M.L. 2011. Propolis research and the chemistry of plant products. Nat. Prod. Rep. 28(5):925936. <http://dx.doi.org/10.1039/c0np00072h><PMid:21412546>

Sawicka D., Car H., Borawska M.H. \& Nikliński J. 2012. The anticancer activity of própolis. Folia Histochem. Cytobiol. 50(1):25-37. <http://dx.doi. org/10.5603/FHC.2012.0004><PMid:22532133>

Schinoni M.I. 2006. Fisiologia hepática. Gaz. Med. Bahia 76(1):5-9.

Sforcin J.M. \& Bankova V. 2011. Propolis: is there a potential for the development of new drugs? J. Ethnopharmacol. 133(2):253-260.<http:// dx.doi.org/10.1016/j.jep.2010.10.032> <PMid:20970490>

Silva R.A., Rodrigues A.E., Ribeiro M.C.M., Custódio Â.R., Andrade N.E.D. \& Pereira W.E. 2006. Características físico-químicas e atividade antimicrobiana de extratos de própolis da Paraíba, Brasil. Ciência Rural 36(6):1842-1848. <http://dx.doi.org/10.1590/S0103-84782006000600027>

Singleton V.L., Orthofer R. \& Lamuela-Raventós R.M. 1999. Analysis of total phenols and other oxidation substrates and antioxidants by means of Folin-Ciocalteu reagent. Methods Enzymol. 299:152-178. <http://dx.doi. org/10.1016/S0076-6879(99)99017-1>

Teerasripreecha D., Phuwapraisirisan P., Puthong S., Kimura K., Okuyama M., Mori H., Kimura A., Chanchao C. 2012. In vitro antiproliferative/cytotoxic activity on cancer cell lines of a cardanol and a cardol enriched from Thai Apis mellifera propolis. BMC Complement. Altern. Med. 30(1):12:27.

Thapa B.R. \& Walia A. 2007. Liver function tests and their interpretation. Indian J. Pediatr. 74(7):663-671. <http://dx.doi.org/10.1007/s12098007-0118-7><PMid:17699976>

Vasconcelos A.C. 1996. Necropsia e conservação de espécimes para laboratório. Cad. Téc. Esc. Vet. Zootec. UFMG. 16:5-30.

Voican C.S., Perlemuter G. \& Naveau S. 2011. Mechanisms of the inflammatory reaction implicated in alcoholic hepatitis: 2011 update. Clin. Res. Hepatol. Gastroenterol. 35(6/7):465-474. <http://dx.doi.org/10.1016/j. clinre.2011.01.017><PMid:21571602>

Waters M.D., Brady A.L., Stack H.F. \& Brockman H.E. 1990. Antimutagenicity profiles for some model compounds. Mutat. Res. 238(1):57-85. <http:// dx.doi.org/10.1016/0165-1110(90)90039-E ><PMid:2406585>

Yogalakshmi B., Viswanathan P. \& Anuradha C.V. 2010. Investigation of antioxidant, anti-inflammatory, and DNA-protective properties of eugenol in thioacetamide-induced liver injury in rats. Toxicology 268(3):204-212. <http://dx.doi.org/10.1016/j.tox.2009.12.018><PMid:20036707>

Zilse G.A.C. \& Silva C.G.N. 2012. Threats to the stingless bees in the brazilian Amazon: how to deal with scarce biological data and an increasing rate of destruction, p.147-168. In: Florio R.M. (Ed.), Bees: biology, threats and colonies. Nova Science Publishers, New York. 